\title{
Calibration and Validation of the SWAT Model on the Watershed of Bafing River, Main Upstream Tributary of Senegal River: Checking for the Influence of the Period of Study
}

\author{
Moussé Landing Sane ${ }^{*}$, Soussou Sambou ${ }^{1}$, Issa Leye ${ }^{1}$, Didier Maria Ndione ${ }^{1}$, Samo Diatta $^{2}$, \\ Ibrahima Ndiaye1, Mamadou Lamine Badji1,2, Seïdou Kane1 \\ ${ }^{1}$ Faculty of Sciences and Technology, Department of Physics, Cheikh Anta Diop University, Dakar, Senegal \\ ${ }^{2}$ UFR Science and Technology, Department of Physics, University of Assane Seck, Ziguinchor \\ Email: *mousselanding.sane@ucad.edu.sn
}

How to cite this paper: Sane, M.L., Sambou, S., Leye, I., Ndione, D.M., Diatta, S., Ndiaye, I., Badji, M.L. and Kane, S. (2020) Calibration and Validation of the SWAT Model on the Watershed of Bafing River, Main Upstream Tributary of Senegal River: Checking for the Influence of the Period of Study. Open Journal of Modern Hydrology, 10, $81-104$

https://doi.org/10.4236/ojmh.2020.104006

Received: March 3, 2020

Accepted: October 25, 2020

Published: October 28, 2020

Copyright $\odot 2020$ by author(s) and Scientific Research Publishing Inc. This work is licensed under the Creative Commons Attribution International License (CC BY 4.0).

http://creativecommons.org/licenses/by/4.0/ (c) (i) Open Access

\begin{abstract}
Management of reservoir water resources requires the knowledge of flow inputs in this reservoir. Hydrological rainfall-runoff model is used for this purpose. There are several types of hydrological model according the description of the hydrological processes: black-box models, conceptual models, deterministic physical based model. SWAT is a semi-distributed hydrological model designed for water quality and quantity. This versatile tool has been used all around the world to assess and manage water resources. The main objective of the paper is to calibrate and validate the SWAT model on the watershed of Bafing located between $10^{\circ} 30^{\prime}$ and $12^{\circ} 30^{\prime}$ north latitude and between $12^{\circ} 30^{\prime}$ and $9^{\circ} 30^{\prime}$ west longitude to assess climate change on this river flows. A DEM with a resolution of $12.5 \mathrm{~m} \times 12.5 \mathrm{~m}$, the daily average flows and the daily observed precipitations on the period 1979-1986 (long period) are used as inputs for the calibration, while precipitations for the period 1988-1994 are used for the validation. The sensitivity analysis was done to detect the most determining coefficients during the calibration step. It shows that 19 parameters are required. Then, the effect of the period on the parameters calibration is checked by considering first the whole period of study and then each year of the period of study. The Nash criterion was used to compare the calculated and the observed hygrographs in each case. The results showed that the longer is the period of calibration, the more accurate is the Nash criterion. The calibration per year gave a best Nash criterion except for a single year. During the validation, the parameters calculated on the long period lead to the best Nash criterion. The values of the Nash criterion calibration and validation are very suitable. These results of calibration can be used
\end{abstract}


to study the long-term evolution of flow at Senegal River on Bafing Makana.

\section{Keywords}

SWAT, Hydrological Modelling, Senegal River, Bafing Makana

\section{Introduction}

To promote self-sufficiency in food scarcity and to promote the income of the local population, to preserve the natural ecosystems and to mitigate the effects of climate change and extremes events and to accelerate their common economic development, Senegal, Mali, Mauritanea and Guinea West African countries have created the Senegal River Basin Development Authority (Organisation pour la Mise en Valeur du fleuve Senegal, OMVS, in French). The objective of this Organisation is of jointly managing the Senegal River and its drainage basin. Diama and Manantali Dam have been built, the first on Delta of Senegal River, the second on the Bafing River, the main tributary of the Senegal River. While Diama Dam aims mainly at stopping sea water intrusion in the Delta, Manantali Dam is a multi-purpose dam on the Bafing river in the Senegal River basin with a reservoir capacity which is of $11.3 \mathrm{~km}^{3}$. The dams system's function is to regulate the Senegal River regime, to provide the water flows needed to irrigate 375,000 hectares, to supply water to urban centers, to make navigation on the river possible, to produce about $800 \mathrm{Kwh}$ of electricity, to cut off natural floods and thus reduce flooding, to prevent the rise of seawater in the low-flows in the delta, to improve the filling conditions of the dams. An accurate estimation of the availability of water resources is required by stakeholders and policy makers need to estimate the availability of water resources to plan and develop a given region. This requires a good understanding of the interactions between precipitations, evapotranspiration, stream flow and water balance at spatial and temporal scales in the catchment. Hydrological models are becoming increasingly useful in devising policies for management of storage reservoirs and mitigating extreme hydrological events like floods and droughts [1]. A hydrological model may be defined as a mathematical representation of the water cycle on a portion of a given catchment, in order to perform rain-runoff transformations. Hydrological models can be classified according to the spatial description of the catchment into lumped and distributed. A lumped model performs a simplified water balance over the whole catchment. Distributed models divide the basin into smaller subareas considering the spatial variability of the data and the model parameters [2]. Distributed hydrological models are now more and more able to simulate most of the complex basin hydrological processes because they can incorporate the remotely sensed and digital elevation model (DEM) data [3]. An intermediate category of models is that of semi-distributed models. In these models, the whole catchment is divided into smaller sub catchments whose characteristics are as uniform as possible. This allows them to combine the advan- 
tages of both lumped and distributed hydrological models [4].

Hydrological models can also be classified according to the way they describe the hydrological processes from conceptual empirical models to physically based distributed parameters models according the way they estimate runoff [5]. In conceptual models, hydrological processes are represented by simplified mathematical equations, while in physically based models, hydrological processes are represented by conservation laws of fluid mechanics: momentum conservation and energy conservation [6]. There are many applications of hydrological modelling in hydrology. [7] used two black-box models (GR2M and GR4J) to assess runoff on the Niger River basin. [8] applied deterministic models WRF-Hydro and HEC-HMS in southern Lebanon, Israel, West Jordan and Eastern Sinai to assess the performance of simulated hydrographs driven by various precipitation sources. [9] used HEC-HMS for flood forecasting in the Sturgeon Creek watershed in Manitoba, Canada. [10] used MIKE SHE to assess the applicability in the large-scale watershed of northern Chian.

GIS based models are very useful in management of storage reservoirs and mitigating extreme hydrological events. Among these models, SWAT is becoming more and more very popular in the community of water resources practitioners. SWAT is a hydrological model that allows simulating the quantity (stream flow) and quality (pesticides, nutrients and sediments) of water [11] [12]. It also quantifies the impact of land management practices in large and complex watersheds. SWAT includes many useful components and functions for simulating the water balance and the other watershed processes such as water quality, climate change, crop growth, and land management practices. The SWAT model is a well-known tool, widely used in several cases in the word, and successfully adapted [13]. Authors such as [14] [15] [16] have used SWAT to simulate sediment yields and nutrient transfer processes. [17] modeled a four million $\mathrm{km}^{2}$ area in West Africa, including mainly the basins of the rivers Niger, Volta and Senegal with SWAT. [18] presented a set of papers where the SWAT model has been used in different fields.

SWAT is characterized by a large number of parameters related to hydrology, water quality, biomass and crop yields predictions. Proper use of this model requires two or three phases: sensitivity analysis, calibration and Validation. The sensibility analysis is very important to reduce the number of parameters and to determine the accurate of these parameters. [19] measures the significant of a parameter by determining the sensitivity of this parameter and the p-value with tstat. Since greater changes in output variables correspond to greater sensitivities, [20] measures the response of an output variable to the change in an input parameter with sensitivity index. The calibration consists to determine the model parameters; the validation ensures that the parameters describe very well the hydrological behavior of the watershed. The calibration procedure involved the adjustment of the SWAT parameters by using SWAT-CUP, PARASOL, SUFI-2 or manually to check for the adequacy between SWAT calculated outflows the observed outflows. Swat model has been used to simulate streamflow and the 
hydrological behavior of basins. [21] calibrated and validated SWAT model using hydrometeorological data from 1988 to 2001 on Xitiaoxi catchment situated in Huzhou, a city in northern Zhejiang Province. [22] applied an automated calibration procedure implemented in SWAT2003 called PARASOL (Parameter Solution Method) on Biobio River Basin located in Central Chile. SUFI-2 algorithm was used by [23] for the calibration SWAT model of the upstream gauge (Hester Creek) and downstream gauge (Flint River) for the monthly and daily flows. [24] used SWAT-CUP for automatic calibration of stream flow at Musi basin. SWAT has been applied in America, Asia, Europe and Africa on various watersheds extending from 3.35 to $114,345 \mathrm{~km}^{2}$ [25] [26] and [27] to assess impact of climate change on water resources between 2046-2064 and 2080-2100 respectively on lasser Zab and Al-Adhaim localed at Iraq; [28] to simulate the impact on local hydrology of a small agricultural watershed three climate change scenarios; [29] to simulate the impact of potential climate change on Creek basin hydrology; [30] to study the hydrological behaviour of the Sebou watershed (Morocco), [31] to simulate stream flow and estimate sediment yield and nutrients loss from the Murchison use this model. The objective of this paper is to describe the rainfall-run off processes in the catchment of the Bafing River, the main tributary of Senegal River upstream Bafing Makana stream gauge. The final result is to help decision-makers of the OMVS in water resources managements. Empirical conceptual models such as GR4J at daily step and GR4J at monthly steps have already been calibrated and validated on the Bakoye, Faleme and Bafing tributaries to simulate rainfall runoff processes [32] [33] and [34]. These models are not well suited when characteristics of basin should be taken into account. That is why SWAT model has been used in this paper to simulate rainfall runoff processes on the river basin of Bafing River upstream Bafing Makana gauge station to estimate inputs flows at the Manantali Dam. The most sensitive parameters have estimated once a sensitivity analysis has been carried out. These parameters have been calibrated and validated on the whole period of study and on every year of the period of study then. Criteria of goodness of fit values indicate the SWAT hydrological model can be used to estimate the flow of the Bafing River at the Bafing Makana gauge station. Estimated and observed hydrographs have been compared through plots. Parameters estimated on the whole period of study have been found to be the best.

\section{Materials and Methods}

\subsection{Study Area}

Senegal River originates in the Fouta Djalon mountains, in West AFrica. It crosses the countries of Guinea, Mali Mauritania and Senegal. This Basin Organization for the Development of the Senegal River (OMVS) is a regional cooperative management body of the Senegal River which currently includes Guinea, Mali, Mauritania, and Senegal. The study area is the watershed of Bafing located between $10^{\circ} 30^{\prime}$ and $12^{\circ} 30^{\prime}$ north latitude and between $12^{\circ} 30^{\prime}$ and $9^{\circ} 30^{\prime}$ west longitude [35] [36]. Bafing River is characterized by tropical climate with 
annual mean temperature is $27.6^{\circ} \mathrm{C}$ and annual mean rainfall of $1166 \mathrm{~mm}$ [37]. Figure 1 represents the study area and the area is $22,220 \mathrm{~km}^{2}$.

\subsection{Topographical and Climate Data}

Topography of the watershed was defined by digital elevation model (DEM) clipped out from the Shuttle Radar Topography Mission (SRTM) $12.5 \times 12.5 \mathrm{~m}$ Digital Elevation Data https://vertex.daac.asf.alaska.edu/?\#. Rainfall, Max and Min Temperature Solar radiation, RH, wind speed was obtained on

https://globalweather.tamu.edu/. The daily average flows and the daily observed precipitations come from the Organization for the Development of the Senegal River Database.

\subsection{Soils and Land Use}

Land use and land cover map downloaded from the website

(https://www.britannica.com/science) whose resolution is of $1 \mathrm{~km} \times 1 \mathrm{~km}$ for Africa data sets has been used in this study. The Bafing river watershed consists of 4 different soil classes namely Acrisols, Cambisols, Leptosols and Regosols (Figure 2(a)). From the map (Figure 2(b)), it can be observed that there are around 5 classes of Land cover. An acrisol is a type of soil as classified by the Food and Agriculture Organization. It is clay-rich, and is associated with humid,

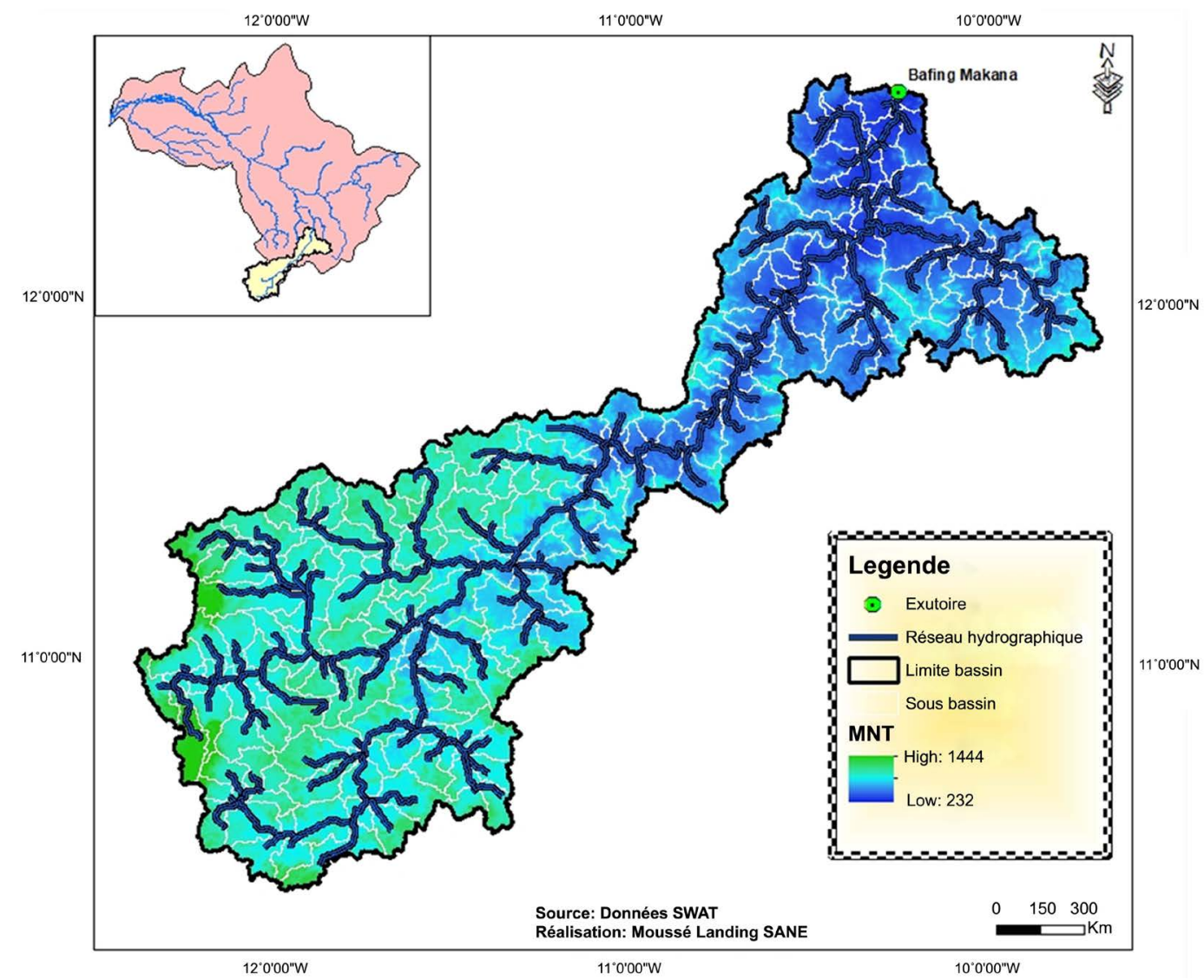

Figure 1. Study area. 


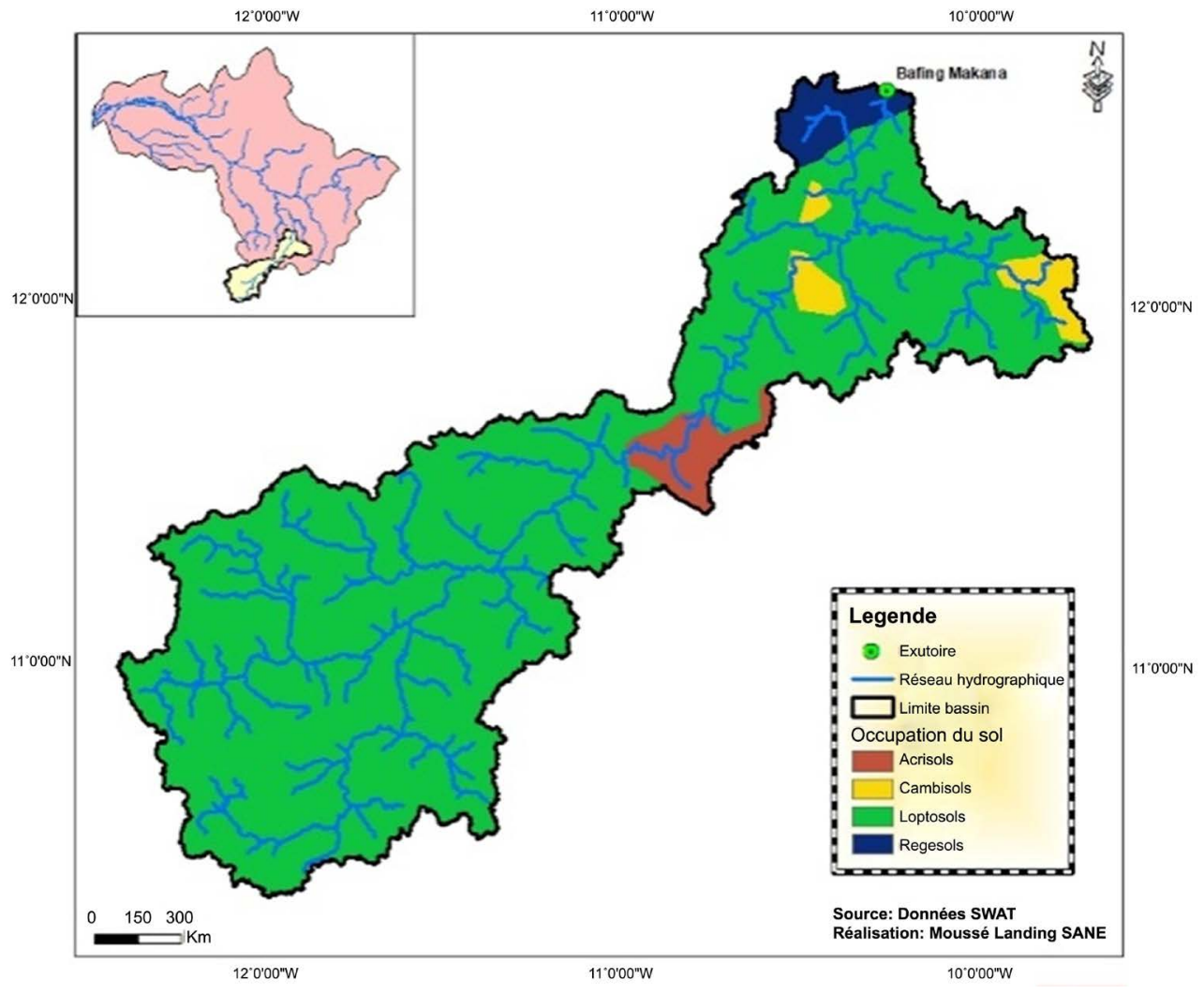

(a)

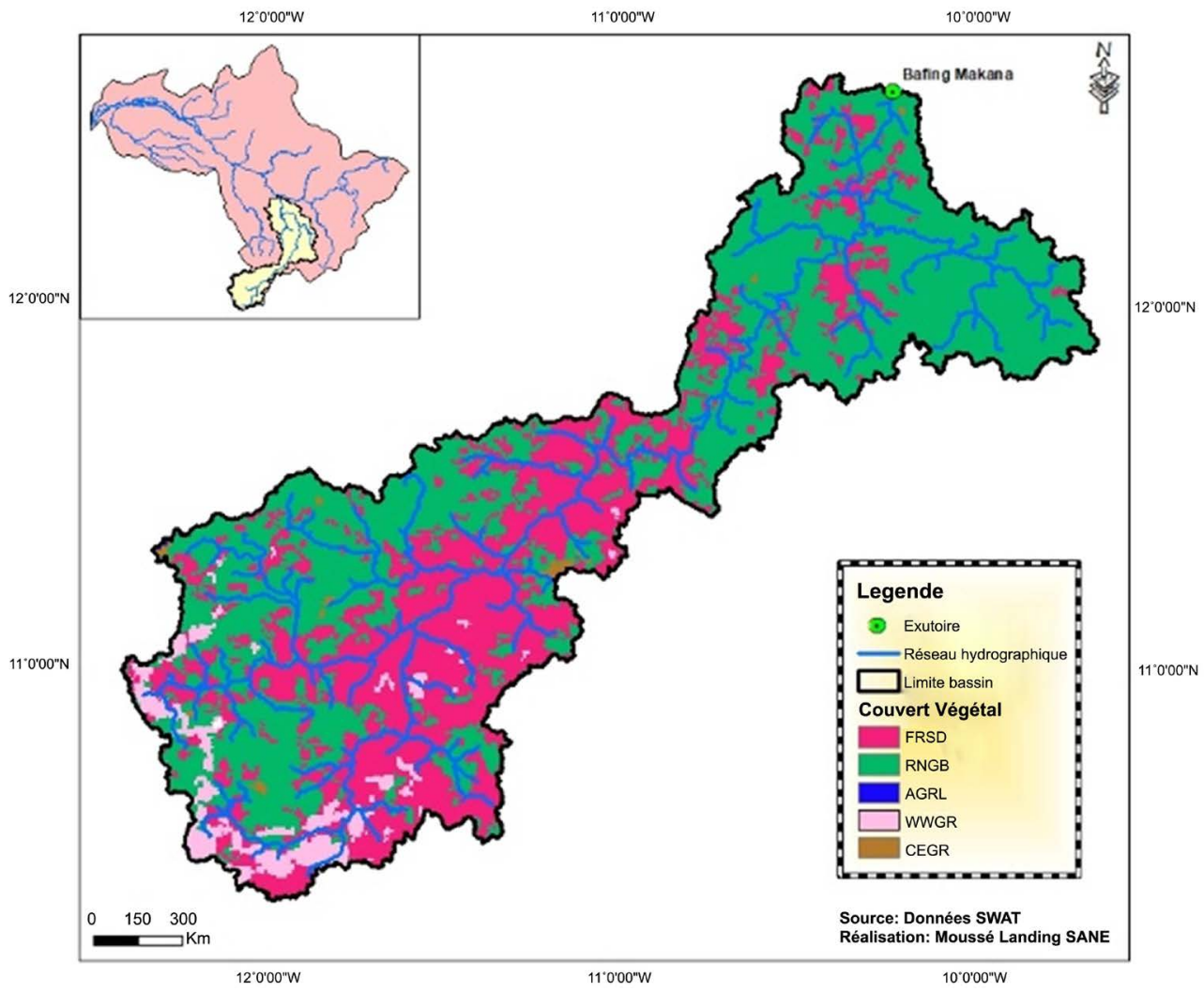

(b)

Figure 2. (a) Soil classes; (b) Land cover. 
tropical climates. A Cambisol is a soil with a beginning of soil formation. Cambisols are developed in medium and fine-textured materials derived from a wide range of rocks, mostly in alluvial, colluvial and aeolian deposits. Leptosol, one of the 30 soil groups in the classification system of the Food and Agriculture Organization (FAO). Leptosols are soils with a very shallow profile depth (indicating little influence of soil-forming processes), and they often contain large amounts of gravel. Leptosols are unattractive soils for rainfed agriculture because of their inability to hold water, but may sometimes have potential for tree crops or extensive grazing. Regosols are characterized by shallow, medium-to fine-textured, unconsolidated parent material that may be of alluvial origin and by the lack of a significant soil horizon (layer) formation because of dry or cold climatic conditions. Regosols in mountain areas are best left under forest. Land use and management of Regosols vary widely. Some Regosols are used for capital-intensive irrigated farming but the most common land use is low volume grazing. Figure 2(b) shows the types of land cover in the watershed. The most important major types of land use in the basin are: FRSD, RNGS, WWGR and CWGR covering of the total basin area Table 1.

\subsection{Description of SWAT Model}

SWAT (Soil and Water assessment Tool) is a semi-empirical and semi-physical based model developed by l'USDA (Agricultural Research Service) and running to daily [38]. It is a basin scale, continuous time, conceptual and long-term simulation model that operates at daily and hourly time step [39]. This model has been developed for with areas from a few hundreds of $\mathrm{km}^{2}$ to several thousands of $\mathrm{km}^{2}$ [40]. SWAT system is embedded within a Geographic Information System (ArcGIS interface), in which different spatial environmental data, including climate, soil, land cover and topographic characteristics can be integrated. SWAT subdivides a watershed into sub-basins connected by a stream network, and further delineates Hydrological Reponses Units (HRU). HRU consists of unique combination of land cover and soils in each sub basin [41]. A kinematic storage is used to predict lateral flow, whereas return flow is simulated by creating shallow aquifer. The Muskingum method is used for channel flood routing [42]. The SWAT model is a comprehensive, continuous river system scale hydrological model that simulates interactions of major hydrological components

Table 1. Characteristics of the soil and land cover in the watershed of Bafing River.

\begin{tabular}{ccccc}
\hline $\begin{array}{c}\text { Corresponding land cover } \\
\text { use in the SWAT model }\end{array}$ & Definition & Area \% & $\begin{array}{c}\text { Corresponding soil use } \\
\text { in the SWAT model }\end{array}$ & Area \% \\
\hline FRSD & Forest Deciduous Mixed & 37.2 & Acrisols & 2.98 \\
RNGB & Range Brush Land & 57.7 & Cambisols & 2.88 \\
AGRL & Agriculture Generic & 0.02 & Leptosols & 91.25 \\
WWGR & Crested wheatgrass & 4.5 & Regosols & 2.87 \\
CWGR & Western wheatgrass & 0.5 & & \\
\hline
\end{tabular}


on a daily time step. It is free and available on http://www.brc.tamus.edu/swat/. The required input data for the SWAT model, are topographic, climatic, soil and land use data [43] [44]. The simulation of the hydrological cycle is based on the water balance, which is carried out considering precipitation, evapotranspiration, surface, lateral and base flow and deep aquifer recharge. The evapotranspiration can be calculated using one of these three methods: Penman-Monteith, Hargreaves and Priestley-Taylor. The Pemman-Monteith method was selected in this case because it uses more physical parameters (daily maximum and minimum temperature, wind speed, humidity and solar radiation). In addition, the Penman-Monteith option in SWAT incorporates the effects of increased $\mathrm{CO}_{2}$ concentration on plant growth and evapotranspiration [45].

SWAT simulates surface runoff with Soil Conservation Service (SCS) curve number $(\mathrm{CN})$ and the Green and Ampt infiltration method [46]. SWAT use three methods for estimating potential ET: Penman-Monteith, Priestly-Taylor, and Hargreaves [47]. In this paper we use Soil Conservation Service (SCS) curve number $(\mathrm{CN})$ for runoff and the Penman-Monteith for potential ET. The hydrological component is based on a water balance equation:

$$
S W_{T}=S W_{0}+\sum_{i=1}^{t}\left(R_{\text {day }}-Q_{\text {surf }}-E_{a}-W_{\text {seep }}-Q_{q w}\right)
$$

where $t$ is the time in days, $S W_{t}(\mathrm{~mm})$ and $S W_{0}(\mathrm{~mm})$ are the final and initial soil water content respectively, $R_{\text {day }}(\mathrm{mm})$ is precipitation, $W_{\text {seep }}(\mathrm{mm})$ is percolation, $Q_{\text {surf }}(\mathrm{mm})$ is runoff, $Q_{g w}(\mathrm{~mm})$ is return flow, and $E_{a}$ is evapotranspiration.

The estimation of surface runoff can be performed by the model using the Soil Conservation Service (SCS) curve number method [48], and her equation is given by:

$$
Q_{\text {surf }}=\frac{\left(R_{\text {day }}+0.2 S\right)^{2}}{\left(R_{\text {day }}+0.8 S\right)}
$$

where is given by Equation (3)

$$
S=25.4\left(\frac{1000}{\mathrm{CN}}-10\right)
$$

$S$ : drainable volume of soil water per unit area of saturated thickness ( $\mathrm{mm} /$ day); $\mathrm{CN}$ = curve number. The Curve Number $(\mathrm{CN})$ is a dimensionless parameter indicating the runoff response characteristic of a drainage basin. The Curve Number method is based on these two phenomena. The initial accumulation of rainfall represents interception, depression storage, and infiltration before the start of runoff and is called initial abstraction.

The Penman-Monteith method is calculated by the following formula Equation (4) [49].

$$
\lambda E=\frac{\Delta \cdot\left(H_{\mathrm{net}}-G\right)+\rho_{\mathrm{air}} \cdot C_{p}\left(e_{z}^{0}-e_{z}\right) / r_{a}}{\Delta \cdot \gamma \cdot\left(1+\frac{r_{c}}{r_{a}}\right)}
$$


where $\lambda E$ is latent heat flux density $\left(\mathrm{MJ} /\left(\mathrm{m}^{2} \cdot \mathrm{d}\right)\right) ; E$ is evaporation rate $(\mathrm{mm} / \mathrm{d})$; $\Delta$ is saturation vapor pressure-the slope of the temperature curve; $H_{\text {net }}$ is net radiation $\left(\mathrm{MJ} /\left(\mathrm{m}^{2} \cdot \mathrm{d}\right)\right) ; G$ is ground heat flux density $\left(\mathrm{MJ} /\left(\mathrm{m}^{2} \cdot \mathrm{d}\right)\right) ; \rho_{\text {air }}$ is air density $\left(\mathrm{kg} / \mathrm{m}^{3}\right) ; C_{p}$ is specific heat at fixed air pressure $\left(\mathrm{MJ} / \mathrm{kg} \cdot{ }^{\circ} \mathrm{C}\right) ; \quad e_{z}^{0}$ is saturated vapor pressure at $z$ height $(\mathrm{kPa}) ; e_{z}$ is the vapor pressure at $z$ height (kPa); $g$ is psychrometric constant $\left(\mathrm{kPa} /{ }^{\circ} \mathrm{C}\right) ; r_{c}$ is the impedance of the vegetation canopy $(\mathrm{s} / \mathrm{m}) ; r_{a}$ is the diffusion impedance of the air layer $(\mathrm{s} / \mathrm{m})$.

The SWAT model has been extensively documented and illustrated in other articles. A detailed description of SWAT, including extensive equations, a flow chart, and a discussion of model limitations, is given by [50].

\subsection{Sensitivity Analysis}

Sensitivity analysis allows reducing the number of parameters to test for effective use of the model. The sensitivity analysis and the calibrations of the model are made using the SWAT-CUP or SUFI-2 program [19] [31]. The use of sensitivity analysis enabled identification of the most important parameters required to model the hydrological processes in the watershed of Bafing River. There are a large number of parameters in the SWAT model. In the literature we find many methods for the assessment of the parameters sensitivity of SWAT model [51] [41]. In this study we use the parameters frequently used in SWAT modeling [7] [20]. A set of 22 model parameters was employed in this sensitivity analysis to obtain surface runoff, percolation, and evapotranspiration processes. The influence coefficient method is one of the most common methods for computing sensitivity coefficients in surface and ground water problems. The method evaluates the sensitivity by changing each of the independent variables, one at a time. A sensitivity coefficient represents the change of a response variable that is caused by a unit change of an explanatory variable, while holding the rest of the parameter constant [52].

Step 1: use default parameters;

Step 2: default parameters are fixed except the one whose sensitivity is to be checked. Step 3: Model is run with the minimum value of this parameter and outputs of the run are stored (PET, Surface runoff, lateral flow, recharge, revap and percolation).

Step 4: Model is run with the maximum value of this parameter outputs of the run are stored (PET, Surface runoff, lateral flow, recharge, revap and percolation).

Step 5: repeat 2 to 5 for all parameters

Step 6: The sensitivity index of this parameter is calculated with outputs of steps 3 and 4 (Equation (3))

The formula of sensitivity index is given by the following Equation (9):

$$
P_{\text {mean }}=\frac{P_{\min }-P_{\max }}{2}
$$




$$
\begin{gathered}
\Delta P=P_{\text {min }}-P_{\text {max }} \\
F_{\text {mean }}=\frac{F_{\text {min }}-F_{\text {max }}}{2} \\
\Delta F=F_{\text {min }}-F_{\text {max }} \\
|C|=\frac{P_{\text {mean }} \cdot \Delta F}{F_{\text {mean }} \cdot \Delta P}
\end{gathered}
$$

Each parameter to check is composed two values (Maximum value et Minimum value).

$C_{i}$ is the sensitivity index

$P_{\min }$ : Minimum value of parameter to check and it corresponds to six output values;

$P_{\max }$ : Maximum value of parameter to check and it corresponds to six output values;

$F_{\min }$ : Is a set of six output values obtained by $P_{\min }$ for each parameter;

$F_{\max }$ : Is a set of six output values obtained by $P_{\max }$ for each parameter.

The ranking depending on order of magnitude of sensitivity index.

\subsection{Calibration and Validation}

The calibration-validation procedure requires the selection of two different periods: one for calibration and a one or more for validation [30]. The calibration procedure involved the adjustment of the SWAT parameters manually or by using SWAT-CUP so that the resulting stream flows matched the observed inflows. In this study the calibration is performed manually. The validation period allows to assess whether the model has been properly settled, using one or more periods different of the calibration period. The choice of the period of study is based on the availability of data series used as inputs: 1961-2013 for river flow, 1963-1986 and 1988-1994 for rainfall, 1979-2013 for Max and Min Temperature Solar radiation, RH, wind speed. The period 1979-1986 was selected for the calibration of SWAT model. The most frequently used calibration procedure is through the optimization of model performances, which is carried out by comparing observed and simulated data. The parameters retained once the sensitivity analysis is performed are then used for the calibration step, first on the whole 8 years of period of study, and then on each year of the period of the study. This leads to nine sets of parameters. For each period of calibration, statistical criterions of goodness of fit indicated in Table 1 are calculated. Therefore, it is recommended that the model is tested to check its performances in real world applications, after calibration and before using it in practice. Such testing procedure is called validation. The validation period is 1988-1994.

\subsection{Performance Evaluation of the Model}

Performance of the model was evaluated in order to assess how well the model simulated values fit the observed values. In Table 2, several statistical measures are available for evaluating the performance of a hydrologic model [53] [54]. These 
are respectively the coefficient of determination $\left(\mathrm{R}_{2}\right)$, the Nash-Sutcliffe efficiency (NSE), the Percent Biais (PBIAS), Root Mean Square Error (RMSE) and Ratio of the RMSE to the standard deviation of the observations (RSR). Nash-Sutcliffe coefficient measures the efficiency of the model and it is efficiencies can range from $-\infty$ to 1 . The coefficient of determination provides a measure of how well observed outcomes are replicated by the model. Percent PIAIS is used for quantifying the volume errors. The RMSE can be positive or negative, it measures the average difference between observed and simulated values. The ratio of the RMSE to the standard deviation of the observations the RSR value and provide additional information. These criterions are very useful in model assessment because the dimensionless form of most of them allows to compare their performances on different catchments or periods.

\section{Results and Discussions}

SWAT model examines six (06) different sections which are: climate, hydrology, erosion, plantation growth, management and quality of water. We note here that our investigation will be focused to the sections "hydrology" only. The results of sensibility analysis, calibration and validation are presented in the following paragraph.

\subsection{Sensitivity Analysis}

The sensitivity analysis allows to detect the sensitive parameters. These parameters will then be used for the calibration of the model. We have selected seven

Table 2. Criteria for evaluating the performance of SWAT model.

\begin{tabular}{|c|c|c|c|c|}
\hline Statistical criterion & Equations & Values & Classification of Performance & References \\
\hline NSE & $1-\frac{\sum\left(Q_{o b s}-Q_{\text {sim }}\right)^{2}}{\sum\left(Q_{o b s}-\bar{Q}_{o b s}\right)^{2}}$ & $\begin{array}{c}0.75<\mathrm{NSE} \leq 1.00 \\
0.65<\mathrm{NSE} \leq 0.75 \\
0.50<\mathrm{NSE} \leq 0.65 \\
0.4<\mathrm{NSE} \leq 0.50 \\
\mathrm{NSE} \leq 0.4 \\
0.4 \leq \mathrm{NSE} \leq 0.70\end{array}$ & $\begin{array}{c}\text { Very good } \\
\text { Good } \\
\text { Satisfactory } \\
\text { Acceptable } \\
\text { Unsatisfactory } \\
\text { Acceptable }\end{array}$ & [53] \\
\hline $\mathrm{R}^{2}$ & $\frac{\sum\left(\left(Q_{o b s}-\bar{Q}_{o b s}\right)\left(Q_{s i m}-\bar{Q}_{s i m}\right)\right)^{2}}{\sum\left(Q_{o b s}-\bar{Q}_{o b s}\right)^{2} * \sum\left(Q_{s i m}-\bar{Q}_{s i m}\right)^{2}}$ & $\mathrm{R}^{2}>0.5$ & $\begin{array}{l}\mathrm{R}^{2} \text { values }>0.5 \text { are regarded as } \\
\text { acceptable for model simulation }\end{array}$ & [54] \\
\hline PBIAS & $\frac{\sum\left(Q_{o b s}-Q_{\text {sim }}\right) * 100}{\sum\left(Q_{o b s}\right)}$ & $\begin{array}{c}\text { PBIAS }< \pm 10 \\
\pm 10 \leq \text { PBIAS }< \pm 15 \\
\pm 15 \leq \text { PBIAS }< \pm 25 \\
\text { PBIAS } \geq \pm 25\end{array}$ & $\begin{array}{l}\text { Very good } \\
\text { Good } \\
\text { Satisfactory } \\
\text { Unsatisfactory }\end{array}$ & [55] \\
\hline RMSE & $\sqrt{\frac{\sum\left(Q_{o b s}-Q_{\text {sim }}\right)}{n}}$ & $\begin{array}{l}\text { Value below half the } \\
\text { standard deviation }\end{array}$ & Satisfactory & [56] \\
\hline RSR & $\sqrt{\frac{\sum\left(Q_{o b s}-Q_{s i m}\right)^{2}}{\sum\left(Q_{o b s}-\bar{Q}_{o b s}\right)^{2}}}$ & $\begin{array}{c}0.00 \leq \mathrm{RSR} \leq 0.50 \\
0.50<\mathrm{RSR} \leq 0.60 \\
0.60<\mathrm{RSR} \leq 0.70 \\
\quad \mathrm{RSR}>0.70\end{array}$ & $\begin{array}{l}\text { Very good } \\
\text { Good } \\
\text { Satisfactory } \\
\text { Unsatisfactory }\end{array}$ & [57] \\
\hline
\end{tabular}

$Q_{o b s}=$ Observed; $Q_{\text {sim }}=$ Simulated; $\bar{Q}_{o b s}=$ Mean observed; $\bar{Q}_{\text {sim }}=$ Mean observed. 
extensions (Sol, Hru, Sub, Rte, Gw, Sub-Largand Mgt) during sensitivity analysis and five of them are finally retained. Increasing Soil parameters leads to increase of surface runoff and decrease of PET. When GW parameters decrease, return flow decreases while revap and recharge increase. When HRU parameters increase, surface runoff, return flow and recharge increase. Table 3 presented the sensibility analysis results. Only eleven parameters are sensitive for surface runoff, eight for Lateral flow, fifteen for Return flow and Revap, and twelve for Recharge.

ALPHA_BF (days): Baseflow recession coefficient; CN2: Runoff curve parameter; ESCO: Soil evaporation coefficient; SOL_K: Saturated water conductivity coefficient; $\mathrm{CH}$ _K2 $\left(\mathrm{mm} \cdot \mathrm{h}^{-1}\right)$ : River effective water conductivity coefficient; RCHRG_DP: Water table permeation; EPCO: Material transpiration coefficient; GW_delay (days): Delay time for aquifer recharge; GW_revap: Groundwater "revap" coefficient; GWQMN (mm): Threshold water depth in the shallow aquifer for base flow; Lat_Time: Lateral flow travel time; OV_N: Manning's "n"

Table 3. Parameters of sensitivity analysis model.

\begin{tabular}{|c|c|c|c|c|c|c|c|c|c|}
\hline Surface runoff & Order & Lateral flow & Order & Return flow & Order & Recharge & Order & Revap & Order \\
\hline SOL_Z & 1 & SOL_K & 1 & WQMIN & 1 & REVAPMIN & 1 & WQMIN & 1 \\
\hline SOL_K & 2 & SOL_Z & 2 & CH_K1 & 2 & SOL_Z & 2 & SOL_Z & 2 \\
\hline CN2. & 3 & CN2.MGT & 3 & SOL_Z & 3 & CH_K1 & 3 & REVAPMIN & 3 \\
\hline CANMX & 4 & LAT_TTIME & 4 & REVAPMIN & 4 & DELAY & 4 & SOL_K & 4 \\
\hline CH_K1 & 5 & CANMX & 5 & DELAY & 5 & SOL_K & 5 & DELAY & 5 \\
\hline LAT_TTIME & 6 & SOL_AWC & 6 & SOL_K & 6 & CN2.MGT & 6 & CN2.MGT & 6 \\
\hline SOL_CBN & 7 & SOL_BD & 7 & CN2.MGT & 7 & CANMX & 7 & CH_K1 & 7 \\
\hline SOL_BD & 8 & SOL_CBN & 8 & CANMX & 8 & RCHRG_DP & 8 & CANMX & 8 \\
\hline SOL_AWC & 9 & CH_K1 & & SOL_BD & 9 & SOL_BD & 9 & SOL_AWC & 9 \\
\hline CH_N1 & 10 & CH_N1 & & OV_N & 10 & SOL_AWC & 10 & RCHRG_DP & 10 \\
\hline OV_N & 11 & OV_N & & CH_N1 & 11 & SOL_CBN & 11 & SOL_BD & 11 \\
\hline ESCO & & ESCO & & RCHRG_DP & 12 & ALPHA_BF. & 12 & REVAP.GW & 12 \\
\hline EPCO & & EPCO & & ALPHA_BF. & 13 & CH_N1 & & ESCO & 13 \\
\hline CH-N2 & & CH-N2 & & SOL_AWC & 14 & $\mathrm{OV} \_\mathrm{N}$ & & EPCO & 14 \\
\hline $\mathrm{CH}-\mathrm{K} 2$ & & $\mathrm{CH}-\mathrm{K} 2$ & & REVAP.GW & 15 & LAT_TTIME & & ALPHA_BF & 15 \\
\hline DELAY & & DELAY & & SOL_CBN & & ESCO & & SOL_CBN & \\
\hline ALPHA_BF & & ALPHA_BF & & LAT_TTIME & & EPCO & & CH_N1 & \\
\hline WQMIN & & WQMIN.GW & & ESCO & & CH-N2 & & OV_N & \\
\hline REVAP & & REVAP.GW & & EPCO & & $\mathrm{CH}-\mathrm{K} 2$ & & LAT_TTIME & \\
\hline REVAPM & & REVAPMIN & & $\mathrm{CH}-\mathrm{N} 2$ & & WQMIN.GW & & $\mathrm{CH}-\mathrm{N} 2$ & \\
\hline RCHRG_DP & & RCHRG_DP & & $\mathrm{CH}-\mathrm{K} 2$ & & REVAP.GW & & $\mathrm{CH}-\mathrm{K} 2$ & \\
\hline SURLAG & & SURLAG & & SURLAG & & SURLAG & & SURLAG & \\
\hline
\end{tabular}


for overland flow; REVAPMN (mm): Threshold depth of water in the shallow aquifer for revap to occur; SOL_AWC: ( $\mathrm{mm} \mathrm{H}_{2} \mathrm{O} / \mathrm{mm}$ soil)-Soil available water capacity; SOL_BD: $\left(\mathrm{g} \cdot \mathrm{cm}^{-3}\right)$ : Moist bulk density; SOL_K $(\mathrm{mm} \cdot \mathrm{h})$ : Saturated hydraulic conductivity; SURLAG (days): Surface runoff; $\mathrm{CH} \_N 2$ : Manning's "n" value of the main channel $\left(\mathrm{m}^{-1} / 3 \mathrm{~s}\right)$; SOL_Z $(\mathrm{mm})$ : Layer depth.

\subsection{Calibration of Model}

Sensitivity analysis gave us a first set of sensitive parameters. These parameters are calibrated manually on the period 1979-1986. The final values are presented in Table 4. In this table, we see that among the 22 parameters checked for sensitivity, only 19 were retained for the calibration and validation. In Table 4 we have presented the nine sets of parameters values. The parameters related to soil are found to be more sensitive when the calibration is done on each year of the period of study (line 2 to 4 , column 2 to 9 ).

In Figure 3 we have presented the time evolution of the more sensitive parameters values when calibration is done year by year on the period of study (from 1979 to 1986), the averaged value of these parameters, and the values of these parameters when calibration is made over the whole period of study (1979-1986).

Table 4. Parameters values after manual calibration.

\begin{tabular}{|c|c|c|c|c|c|c|c|c|c|c|c|c|}
\hline Parameters & 1979 & 1980 & 1981 & 1982 & 1983 & 1984 & 1985 & 1986 & Mean & $\mathrm{SD}$ & RD. & $1979-1986$ \\
\hline SOL_BD & 1.33 & 1.1 & 1.42 & 1.42 & 1.64 & 1.45 & 1.43 & 1.31 & 1.40 & 0.15 & 0.11 & 1.38 \\
\hline SOL_Z & 152 & 13 & 100 & 123 & 126 & 123 & 112 & 100 & 99.57 & 41.15 & 0.41 & 100 \\
\hline SOL_CBN & 7.27 & 7.54 & 7.27 & 7.27 & 7.69 & 7.27 & 7.27 & 7.27 & 7.37 & 0.16 & 0.02 & 8.12 \\
\hline SOL_K & 254 & 254 & 254 & 254 & 254 & 254 & 254 & 254 & 254 & 0.00 & 0.00 & 254 \\
\hline CH_K1 & 300 & 300 & 300 & 300 & 300 & 300 & 300 & 300 & 300 & 0.00 & 0.00 & 300 \\
\hline CH_N1 & 0.089 & 0.089 & 0.089 & 0.089 & 0.089 & 0.089 & 0.089 & 0.089 & 0.09 & 0.00 & 0.00 & 0.089 \\
\hline OV_N & 0.156 & 0.156 & 0.156 & 0.156 & 0.156 & 0.156 & 0.156 & 0.156 & 0.16 & 0.00 & 0.00 & 0.116 \\
\hline LAT_TIME & 0.035 & 0.035 & 0.035 & 0.035 & 0.035 & 0.035 & 0.035 & 0.035 & 0.04 & 0.00 & 0.00 & 0.035 \\
\hline CANMX & 100 & 100 & 100 & 100 & 100 & 100 & 100 & 100 & 100 & 0.00 & 0.00 & 100 \\
\hline ESCO & 0.79 & 0.79 & 0.79 & 0.79 & 0.79 & 0.79 & 0.79 & 0.79 & 0.79 & 0.00 & 0.00 & 0.8 \\
\hline EPCO & 0.8 & 0.8 & 0.8 & 0.8 & 0.8 & 0.8 & 0.8 & 0.8 & 0.80 & 0.00 & 0.00 & 0.9 \\
\hline DELAY & 254 & 254 & 254 & 254 & 254 & 254 & 254 & 254 & 254 & 0.00 & 0.00 & 254 \\
\hline ALPHA_BF & 0.688 & 0.688 & 0.752 & 0.688 & 0.688 & 0.688 & 0.688 & 0.752 & 0.71 & 0.03 & 0.04 & 0.688 \\
\hline WQMIN & 3327 & 3327 & 631 & 3327 & 621 & 621 & 621 & 3327 & 1782 & 1445 & 0.81 & 3327 \\
\hline REVAP & 0.127 & 0.191 & 0.127 & 0.191 & 0.09 & 0.1 & 0.09 & 0.191 & 0.14 & 0.05 & 0.33 & 0.191 \\
\hline REVAPMIN & 0.014 & 0.014 & 0.014 & 0.014 & 0.014 & 0.014 & 0.014 & 0.014 & 0.014 & 0.00 & 0.00 & 0.014 \\
\hline RCHRG_DP & 0.42 & 0.42 & 0.95 & 0.42 & 0.42 & 0.45 & 0.42 & 0.42 & 0.50 & 0.19 & 0.37 & 0.42 \\
\hline
\end{tabular}




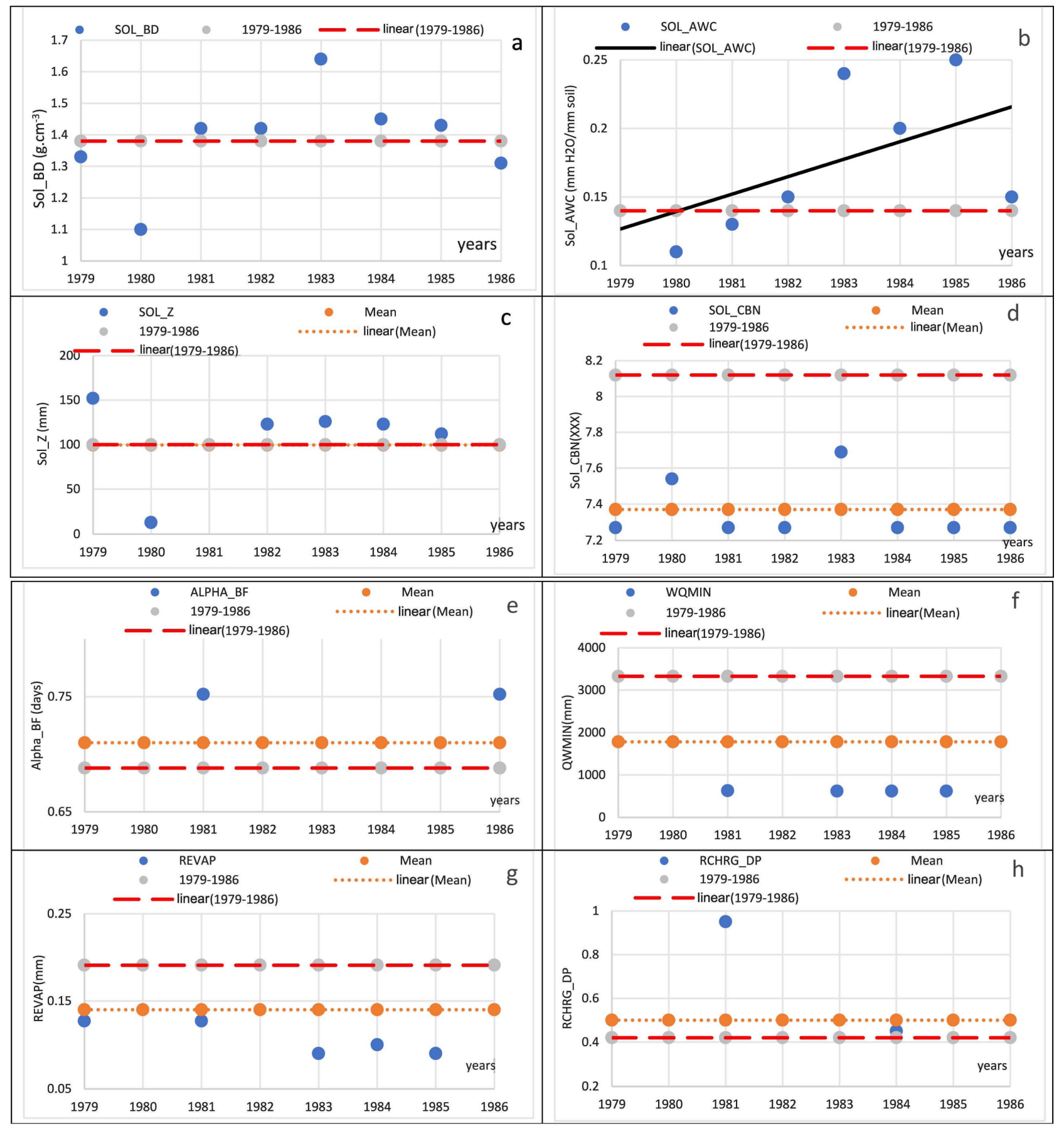

Figure 3. Evolution of the parameters.

The Sol_BD (Figure 3(a)), the parameters values are neighboring from that obtain from period 1979-1986. The Sol_AWC (Figure 3(b)), the values are trend to increase year in and year. The Sol_Z (Figure 3(c)), the parameters values are stabilizing from the year 1981. The Sol_CNB (Figure 3(d)), all parameters values are bellowed of the value of the period 1979-1986. The Alpha_BF (Figure $3(\mathrm{e})$ ), only two parameters values are above of the parameter value from period 1979-1986. The QWMIN (Figure 3(f)) and The Revap (Figure 3(g)), all values 
of this parameters are above of the average. The RCHRG_DP (Figure 3(h)), the parameters obtained are the same that obtain from period 1979-1986 except the parameters of years 1981 and 1984.

In Table 5, we compare the global criteria for evaluating the performance of the calibration (column 2 to 6 ), the mean observed and model simulated flow on the period of calibration (column 7 and 8) and the observed and model simulated depth of runoff on the period of calibration (column 9 and 10). According to Table 1, global criteria for evaluating the performance of the calibration (column 2 to 6 ) are very good except the $\mathrm{R}_{2}$ which is acceptable.

In Figure 4 we plot observed mean annual flow against model simulated mean annual flow (Figure 4), and observed depth of runoff against model simulated depth runoff (Figure 4). The determinant coefficient is about 0.8 what corresponds to a good adequation.

The following Figure 5 presents the daily observed and simulated flow hydrograph when calibration is made year by year. Main features of the hydrographs are restituted by the model.

Figure 6 represents the terms of water balance corresponding to calibration made on every year of the period of study. We have noticed generally downward trend for time series of most terms of water balance (PET, Precipitation, Surface runoff, percolation, and recharge) except return flow and lateral flow time series where an upwards trend is observed. While Revap time serie seems to be trend free. What is remarkable here is that surface run off, percolation, and Recharge present null values for years 1983, 1984 and 1985 where rainfall is particularly low. And there are zero values for runoff and recharge in the same years between 1983 and 1985. For return flow rates, the null values are observed for years 1979, 1980, 1982 and 1983.

We plot in Figure 7 the simulated mean annual flow against observed mean annual flow for calibration period (Figure 7(a) and Figure 7(b)). We have the confirmation that model underestimates peak flow and annual mean flow on the period of study and has difficulties to reproduce peak flow and mean annual flow: corresponding R2 values are very low.

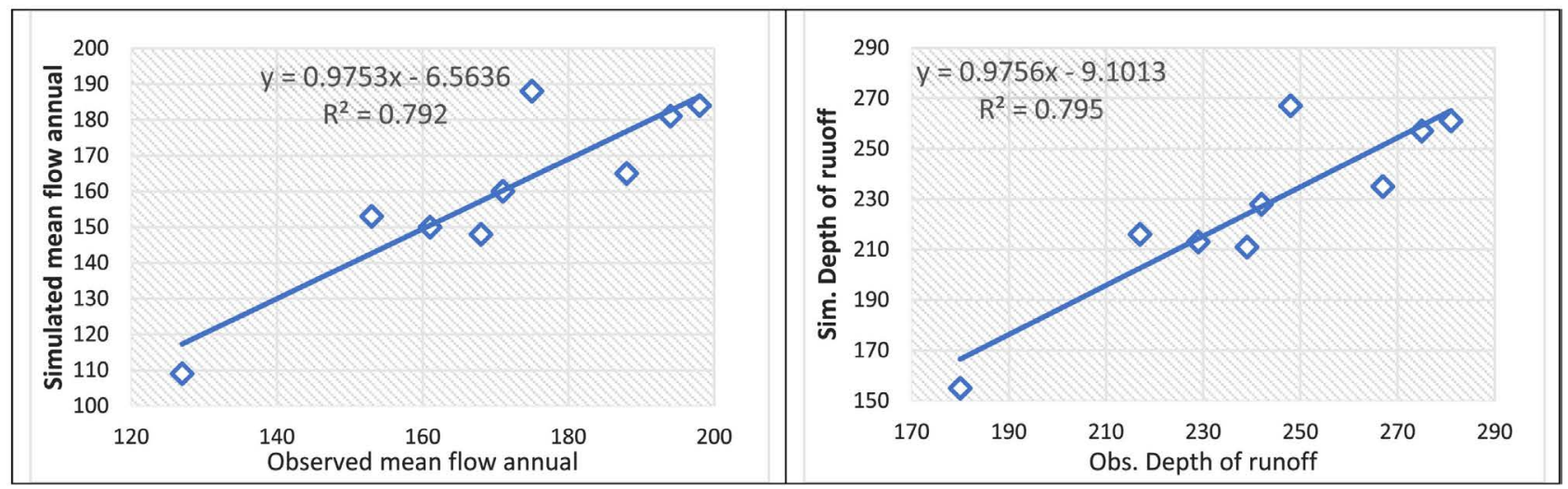

Figure 4. Comparison of annually observed and simulated mean flow and depth runoff for calibration. 


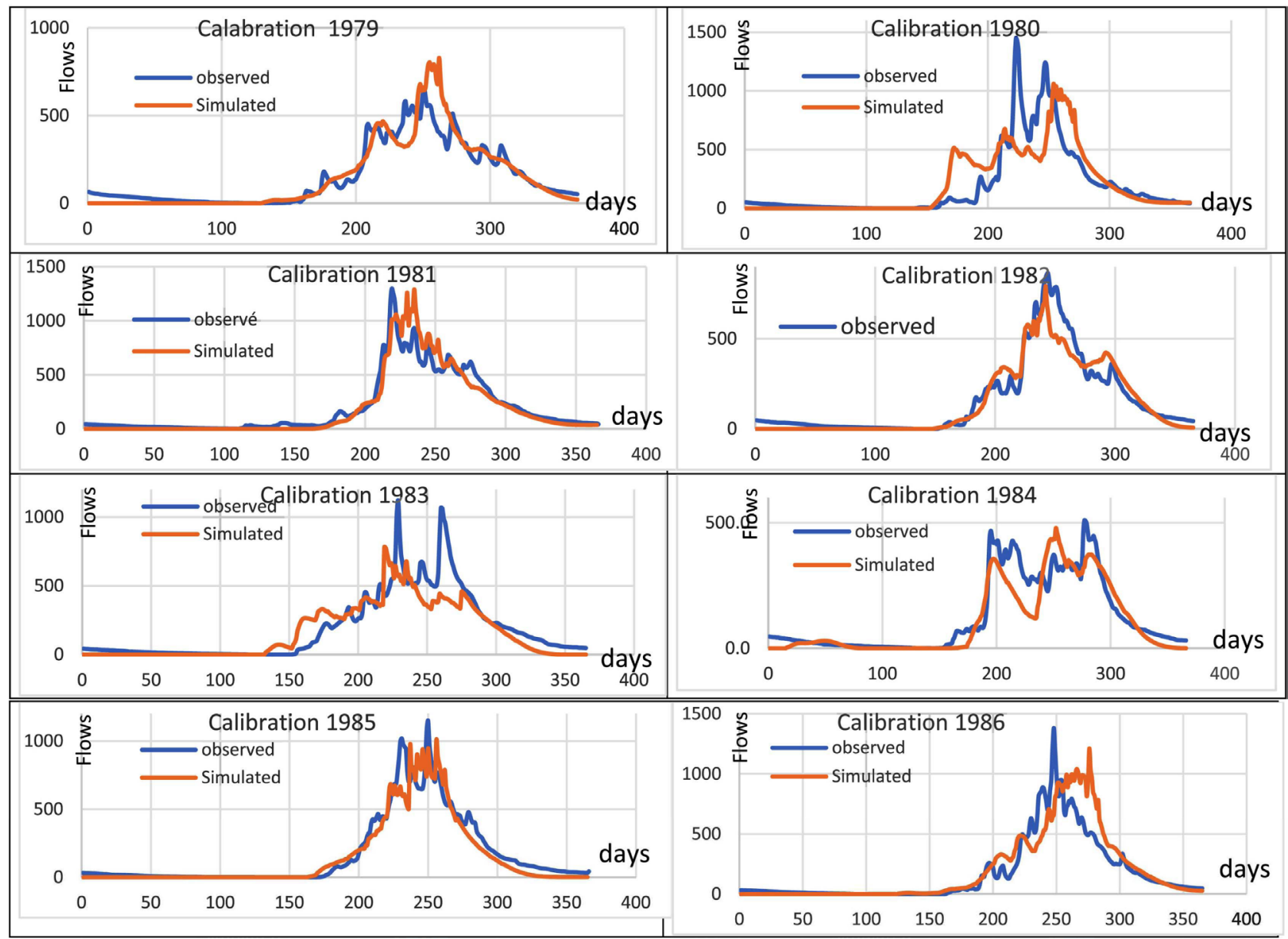

Figure 5. Comparison of daily observed and simulated stream flow for the calibration by year.

Table 5. Criteria for evaluating the performance of SWAT and Statistic evaluation of simulated versus observed average daily stream flow data on calibration.

\begin{tabular}{|c|c|c|c|c|c|c|c|c|c|}
\hline Years & Nash & $\mathrm{R}^{2}$ & PBIAS & RMSE & RSR & $\begin{array}{l}\text { Obs. flow } \\
\left(\mathrm{m}^{3} / \mathrm{s}\right)\end{array}$ & $\begin{array}{c}\text { Sim. flow } \\
\left(\mathrm{m}^{3} / \mathrm{s}\right)\end{array}$ & $\begin{array}{l}\text { Obs. Depth of } \\
\text { runoff }(\mathrm{mm})\end{array}$ & $\begin{array}{l}\text { f Sim. Depth of } \\
\text { runoff }(\mathrm{mm})\end{array}$ \\
\hline 1979-1986 & 0.71 & 0.71 & 4.56 & 2.4 & 0.55 & 171 & 160 & 242 & 228 \\
\hline 1979 & 0.82 & 0.86 & 0.11 & 3.77 & 0.42 & 153 & 153 & 217 & 216 \\
\hline 1980 & 0.54 & 0.55 & 6.6 & 10.55 & 0.68 & 194 & 181 & 275 & 257 \\
\hline 1981 & 0.9 & 0.92 & 7.02 & 4.43 & 0.32 & 198 & 184 & 281 & 261 \\
\hline 1982 & 0.9 & 0.91 & 6.83 & 3.44 & 0.31 & 161 & 150 & 229 & 213 \\
\hline 1983 & 0.72 & 0.73 & 12.17 & 6.59 & 0.53 & 188 & 165 & 267 & 235 \\
\hline 1984 & 0.82 & 0.84 & 14.25 & 3.25 & 0.42 & 127 & 109 & 180 & 155 \\
\hline 1985 & 0.91 & 0.92 & 9.82 & 4.02 & 0.3 & 168 & 148 & 239 & 211 \\
\hline 1986 & 0.77 & 0.8 & -8.43 & 6.49 & 0.48 & 175 & 188 & 248 & 267 \\
\hline Mean & 0.80 & 0.82 & 6.05 & 5.32 & 0.43 & 171 & 160 & 242 & 227 \\
\hline SD & 0.12 & 0.12 & 6.76 & 2.32 & 0.12 & & & & \\
\hline Performance & Very Good & Acceptable & Very Good & & Very Good & & & & \\
\hline
\end{tabular}




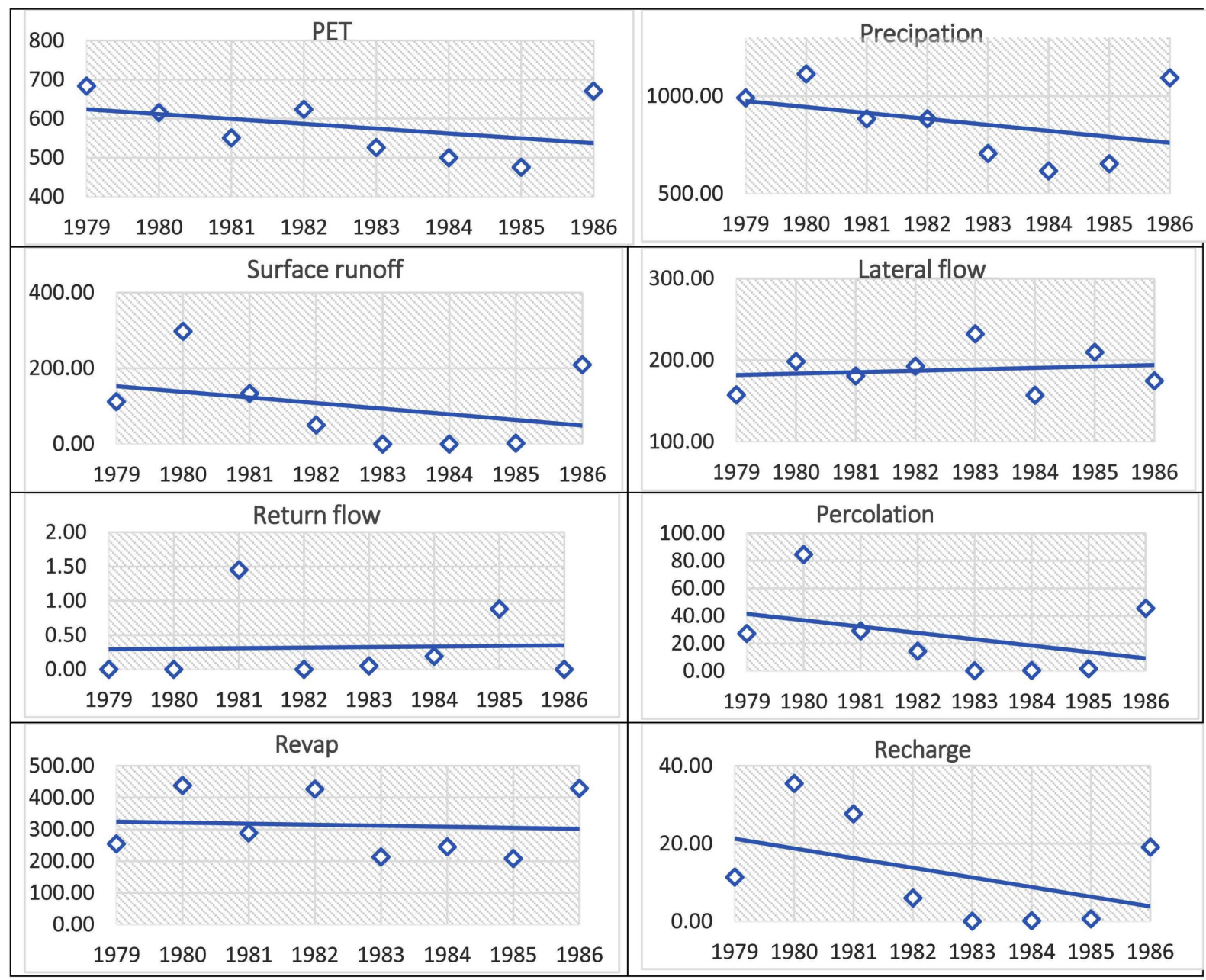

Figure 6. Water balance terms.

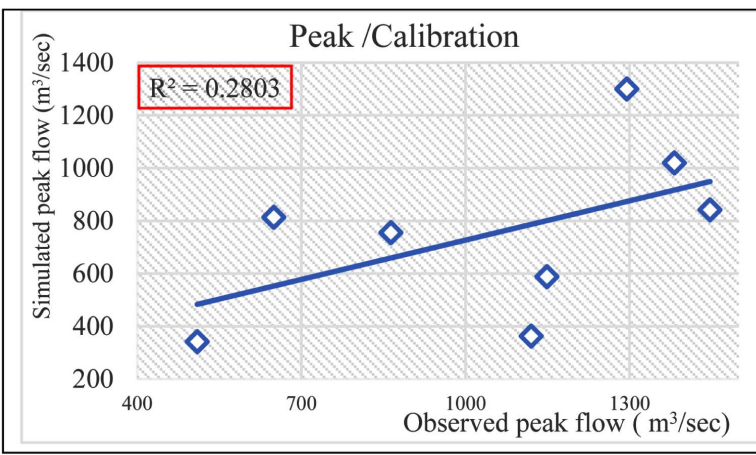

(a)

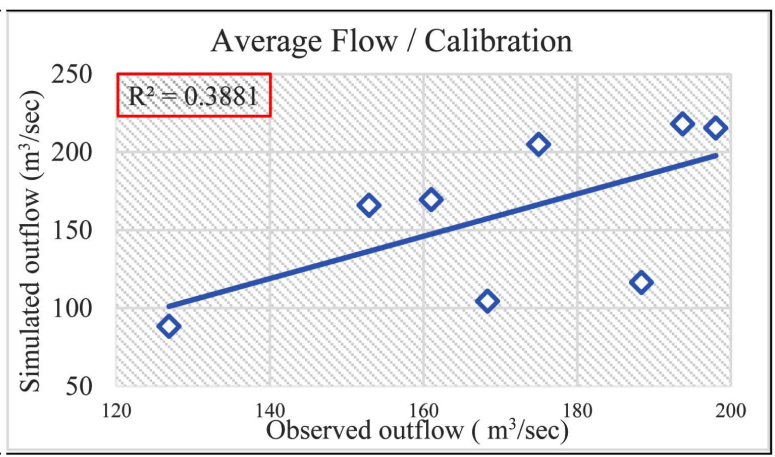

(b)

Figure 7. Comparison of annually observed and simulated peak and average flow for the calibration period.

\subsection{Effect of the Period of Calibration on the Parameters}

The initial period was divided into 36 and the application results of parameters calibrated on the period 1979-1986 were presented in Table 6. The calibration period varies from two years to seven years. The Nash criteria are generally good over the periods studied. According to the lines A, B, D and E, we note that the 
Table 6. Period effect.

\begin{tabular}{|c|c|c|c|c|c|c|c|c|c|}
\hline & 1 & 2 & 3 & 4 & 5 & 6 & 7 & 8 & \\
\hline Period & 1979 & 1980 & 1981 & 1982 & 1983 & 1984 & 1985 & 1986 & \\
\hline NSE & 0.77 & 0.47 & 0.88 & 0.90 & 0.5 & 0.72 & 0.75 & 0.72 & \\
\hline Period & $1979-1980$ & 1979-1981 & 1979-1982 & $1979-1983$ & 1979-1984 & $1979-1985$ & 1979-1986 & & \\
\hline NSE & 0.54 & 0.67 & 0.72 & 0.68 & 0.69 & 0.70 & 0.70 & & A \\
\hline Period & $1980-1981$ & $1980-1982$ & $1980-1983$ & $1980-1984$ & $1980-1985$ & $1980-1986$ & & & \\
\hline NSE & 0.66 & 0.71 & 0.60 & 0.68 & 0.70 & 0.70 & & & B \\
\hline Period & $1981-1982$ & $1981-1983$ & 1981-1984 & 1981-1985 & $1981-1986$ & & & & \\
\hline NSE & 0.89 & 0.77 & 0.77 & 0.76 & 0.76 & & & & $\mathrm{C}$ \\
\hline Period & $1982-1983$ & $1982-1984$ & $1982-1985$ & $1982-1986$ & & & & & \\
\hline NSE & 0.69 & 0.70 & 0.72 & 0.72 & & & & & $\mathrm{D}$ \\
\hline Period & $1983-1984$ & 1983-1985 & $1983-1986$ & & & & & & \\
\hline NSE & 0.57 & 0.65 & 0.67 & & & & & & $\mathrm{E}$ \\
\hline Period & 1984-1985 & 1984-1986 & & & & & & & \\
\hline NSE & 0.74 & 0.73 & & & & & & & $\mathrm{~F}$ \\
\hline Period & $1985-1986$ & & & & & & & & \\
\hline NSE & 0.73 & & & & & & & & G \\
\hline Nash Mean & 0.70 & 0.67 & 0.73 & 0.75 & 0.66 & 0.71 & 0.73 & 0.72 & $\mathrm{H}$ \\
\hline Performance & Good & Good & Good & Good & Good & Good & Good & Good & \\
\hline
\end{tabular}

Nash value increases as the period of calibration increases. On the lines $\mathrm{C}$ and $\mathrm{F}$ of this table, we note that the Nash criterion decreases as the period of calibration period increases. The results presented in this table show that with a few exceptions, Nash's criterion is better when the calibration period is long.

The parameters calibrated on each year were applied on the period 1979-1986 and the results were presented in Table 7. The NSE value (0.69) obtained with the para-meters of year 1982 is the best. The mean value of this criterion is 0.57 .

A total 9 sets parameters were obtained during the calibration phase among this sets parameter those from 1979-1986 were showed a better result into the calibration and application. All parameters are used for the validation but the parameters of period 1979-1986 were retained for the validation of model.

\subsection{Validation of Model}

The model is validated on the period 1988-1994 with the 9 sets calibrated parameters. We present the results in Table 8. Based on the values of all the criteria, the set of parameters calibrated over the global calibration period better represents the Bafing River watershed upstream of Bafing Makana gauge station.

We plot the simulated and observed peak flows (Figure 8(a)), and the simulated and observed mean annual flows Figure 8 (b) for validation period. It appears that model underestimates both peak flows and annual mean flows. 
Table 7. Application of the parameters calibrated per year on the long period.

\begin{tabular}{cccccc}
\hline Years & NSE & $\mathrm{R}^{2}$ & PBIAS & RMSE & RSR \\
\hline 1979 & 0.68 & 0.7 & 11.94 & 2.46 & 0.56 \\
1980 & 0.66 & 0.67 & 4.9 & 2.56 & 0.58 \\
1981 & 0.66 & 0.69 & -10.96 & 2.58 & 0.59 \\
1982 & 0.69 & 0.72 & 1.89 & 2.43 & 0.55 \\
1983 & 0.24 & 0.70 & -36.87 & 3.83 & 0.87 \\
1984 & 0.57 & 0.70 & -14.52 & 2.87 & 0.65 \\
1985 & 0.39 & 0.69 & -27.77 & 3.42 & 0.78 \\
1986 & 0.68 & 0.70 & 9.61 & 2.46 & 0.56 \\
Mean & 0.57 & 0.70 & -7.72 & 2.83 & 0.64 \\
SD & 0.17 & 0.01 & 17.92 & 0.52 & 0.12 \\
Performance & Satisfactory & Acceptable & Very Good & & Satisfactory \\
\hline
\end{tabular}

Table 8. Criteria for evaluating the performance of SWAT and Statistic evaluation of simulated versus observed average daily stream flow data on validation.

\begin{tabular}{|c|c|c|c|c|c|c|c|c|c|}
\hline & Nash & $\mathrm{R}^{2}$ & PBIAS & RMSE & RSR & $\begin{array}{l}\text { Obs. } \\
\text { flow } \\
\left(\mathrm{m}^{3} / \mathrm{s}\right)\end{array}$ & $\begin{array}{l}\text { Sim. flow } \\
\left(\mathrm{m}^{3} / \mathrm{s}\right)\end{array}$ & $\begin{array}{l}\text { Obs. Depth } \\
\text { of runoff } \\
(\mathrm{mm})\end{array}$ & $\begin{array}{c}\text { Sim. Depth } \\
\text { of runoff } \\
(\mathrm{mm})\end{array}$ \\
\hline 1979-1986 & 0.65 & 0.67 & 18.24 & 3.41 & 0.59 & 201 & 165 & 286 & 234 \\
\hline 1979 & 0.63 & 0.67 & 24.84 & 3.50 & 0.61 & 201 & 151 & 286 & 215 \\
\hline 1980 & 0.64 & 0.66 & 15.33 & 3.46 & 0.60 & 201 & 170 & 286 & 240 \\
\hline 1981 & 0.63 & 0.63 & 5.21 & 3.52 & 0.61 & 201 & 191 & 286 & 271 \\
\hline 1982 & 0.64 & 0.66 & 16.1 & 3.43 & 0.60 & 201 & 169 & 286 & 240 \\
\hline 1983 & 0.42 & 0.60 & -18.70 & 4.38 & 0.76 & 201 & 239 & 286 & 339 \\
\hline 1984 & 0.60 & 0.63 & 1.51 & 3.62 & 0.63 & 201 & 198 & 286 & 281 \\
\hline 1985 & 0.52 & 0.61 & -10.04 & 3.99 & 0.69 & 201 & 221 & 286 & 314 \\
\hline 1986 & 0.62 & 0.65 & 23.01 & 3.56 & 0.62 & 201 & 155 & 286 & 220 \\
\hline Mean & 0.59 & 0.64 & 7.16 & 3.22 & 0.64 & 201 & 184 & 286 & 262 \\
\hline SD & 0.08 & 0.03 & 15.63 & 0.29 & 0.06 & & & & \\
\hline Performance & Sat. & Acc. & VG. & & Sat. & & & & \\
\hline
\end{tabular}

SAT $=$ Satisfactory; Acc $=$ Acceptable $;$ VG $=$ Very Good

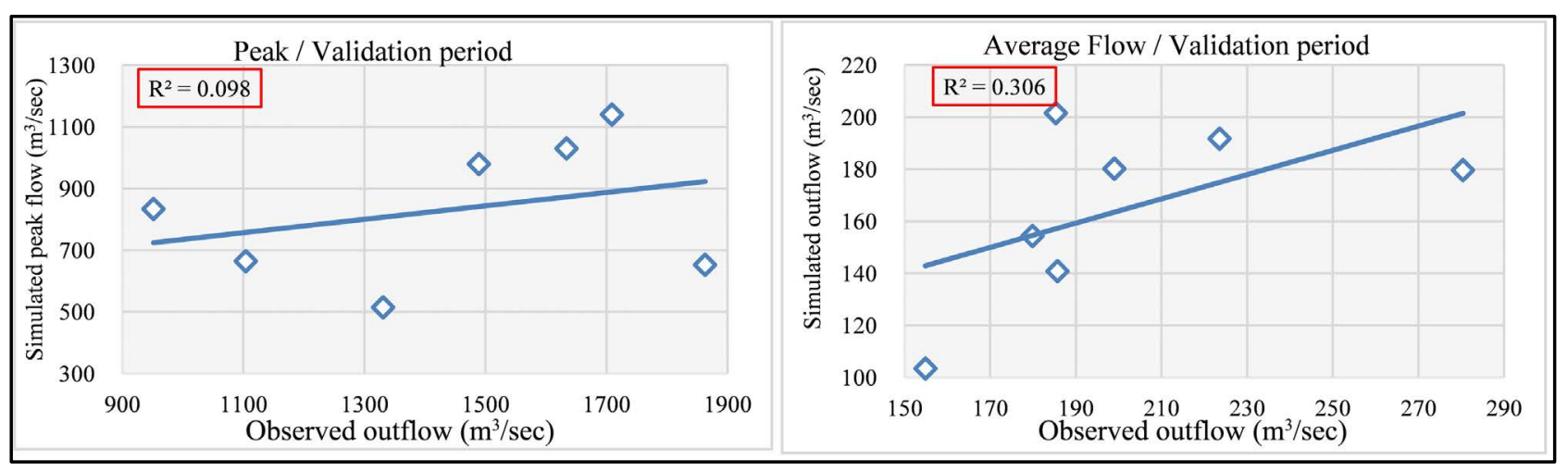

Figure 8. Comparison of annually observed and simulated peak and average flow for the validation period. 


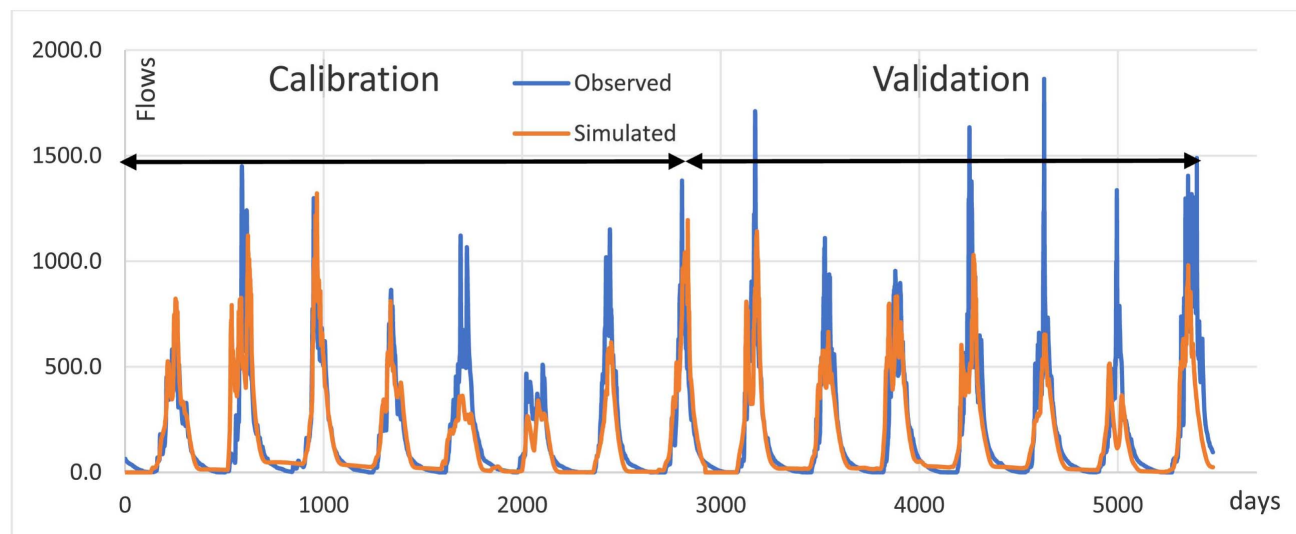

Figure 9. Comparison of daily observed and simulated stream flow for the calibration and the validation period.

Period of study has difficulties to reproduce peak flow and mean annual flow: corresponding $\mathrm{R}_{2}$ values are very low.

Figure 9 presents the results of calibration and validation on the whole period of study. It appears clearly that the model satisfactorily reflects the watershed's hydrological behaviour.

\section{Conclusion}

The objective of this study is to calibrate and validate the SWAT model on Bafing River, the main tributary of Senegal River at upstream Manantali Dam. Sensitivity analysis has first been carried out to detect the most sensitive parameters. 19 parameters have been sensitive among the 22. These parameters have been calibrated first on the whole period of study and the on each year of this period. Validation of the calibrated parameters has been undertaken on the whole period of study (1979-1986) and then on each year of the period of study. According to the Nash Criterion of quality, parameters calibrated on the whole period 1979-1986 are the best. Plots of the estimated and observed hydrographs allow us to assess that SWAT hydrological model can be used to simulate the rainfall-runoff processes on Bafing River basin upstream Bafing Makana gauge station for Manantali Dam operations.

\section{Acknowledgements}

This research was partly funded by the EU funded AICS N.03/2020/WEFESENEGAL project.

\section{Conflicts of Interest}

The authors declare no conflicts of interest regarding the publication of this paper.

\section{References}

[1] Loliyana, V.D. (2015) Lumped Conceptual Hydrological Model for Purna River Ba- 
sin, India. Sadhana, 40, 2411-2428.

[2] Oñate-Valdivieso, F., Bosque-Sendra, J., Sastre-Meruor, A. and Ponce, V.M. (2016) Calibration, Validation and Evaluation of a LUMPED Hydrologic Model in a Mountain Area in Southern Ecuador. Agrociencia, 50, 915-963.

[3] Gan, T.Y., Gusev, Y., Burghes, S.J. and Nasanova, O. (2006) Performance Comparison of a Complex Physics-Based Land Surface Model and a Conceptual, Lumped-Parameter Hydrological Model at the Basin-Scale. IAHS-AISH Publication, 307, 196-207.

[4] Ntoandis, L.I. and Mimikou, M.A. (2013) Intercomparisons of the Lumped versus Semi-Distributed HEC-HMS Hydrological Model in the Kalamus Rivers Basin. Proceedings of Environmental Science and Technology, Athens, 5-7 September 2013, 1-8.

[5] Jain, M. and Sharma, S.T. (2014) Hydrological Modeling of Vam Sadhara River Basin, India, Using SWAT. International Conference on Emerging Trends in Computer and Image Processing (ICETCIP 2014), Paltaya, 15-16 December 2014, 82-86.

[6] Islam, Z. (2011) A Review on Physically Based Hydrologic Modelling. Department of Civil Engineering, University of Alberta, Alberta.

[7] Salou, B.I.G. (2009) Estimation des apports au lac saint-charles à l'aide du modèle hydrologique swat. Mémoire présenté à la Faculté des études supérieures de l'Université Laval dans le cadre du programme de maîtrise en génie civil pour l'obtention du grade de Maître es sciences. Université Laval, Québec.

[8] Givati1, A., Gochis, D., Rummler, T. and Kunstmann, H. (2016) Comparing One-Way and Two-Way Coupled Hydrometeorological Forecasting Systems for Flood Forecasting in the Mediterranean Region. Hydrology, 3, 19. https://doi.org/10.3390/hydrology3020019

[9] Bhuiyan, H.A.K.M., Mcnairn, H., Powers, J. and Merzouki, A. (2017) Application of HEC-HMS in a Cold Region Watershed and Use of RADARSAT-2 Soil Moisture in Initializing the Model. Hydrology, 4, 9. https://doi.org/10.3390/hydrology4010009

[10] Wang, S., Zhang, Z., Sun, G., Strauss, P., Guo, J., Tang, Y. and Yao, A. (2012) Multi-Site Calibration, Validation, and Sensitivity Analysis of the MIKE SHE Model for a Large Watershed in Northern China. Hydrology and Earth System Sciences, 16, 4621-4632. http://www.hydrol-earth-syst-sci.net/16/4621/2012/ https://doi.org/10.5194/hess-16-4621-2012

[11] Li, Y.Q., Zhang, S.H. and Peng, Y. (2015) Soil Erosion and Its Relationship to the Spatial Distribution of Land Use Patterns in the Lancang River Watershed, Yunnan Province, China. Agricultural Sciences, 6, 823-833.

https://doi.org/10.4236/as.2015.68080

[12] Chuenchooklin, S. and Pangnakorn, U. (2016) Application of Inflow Model for Weir Irrigation System without Upstream Dam. World Journal of Engineering and Technology, 4, 1-6. https://doi.org/10.4236/wjet.2016.43B001

[13] Mekonnen, B.A., Nazemi, A., Mazurek, K.A., Elshorbagy, A. and Putz, G. (2015) Hybrid Modelling Approach to Prairie Hydrology: Fusing Data-Driven and Process-Based Hydrological Models. Hydrological Sciences Journal, 60, 1473-1489. https://doi.org/10.1080/02626667.2014.935778

[14] Rostamian, R., Jaleh, A., Jidafyuni, M., Mousavi, S.F., Heidarpour, M., Jalalian, A. and Abbaspour, K.C. (2008) Application of a SWAT Model for Estimating Runoff and Sediment in Two Mountainous Basins in Central Iran. Hydrological Sciences Journal, 53, 977-988. https://doi.org/10.1623/hysj.53.5.977

[15] Khanal, S. and Parajuli, P.B. (2013) Evaluating the Impacts of Forest Clear Cutting 
on Water and Sediment Yields Using SWAT in Mississippi. Journal of Water Resource and Protection, 5, 474-483. https://doi.org/10.4236/jwarp.2013.54047

[16] Bieger, K., Hörmann, G. and Fohrer, N. (2015) Detailed Spatial Analysis of SWAT-Simulated Surface Runoff and Sediment Yield in a Mountainous Watershed in China. Hydrological Sciences Journal, 60, 784-800.

https://doi.org/10.1080/02626667.2014.965172

[17] Schuol, J. and Abbaspour, K.C. (2006) Calibration and Uncertainty Issues of a Hydrological Model (SWAT) Applied to West Africa. Advanced in Geosciences, 9, 137-143. https://doi.org/10.5194/adgeo-9-137-2006

[18] Krysanova, V. and White, M. (2015) Advances in Water Resources Assessment with SWAT-An Overview. Hydrological Sciences Journal, 60, 771-783.

[19] Gyamfi, C., Ndambuki, J.M. and Salim, R.W. (2016) Application of SWAT Model to the Olifants Basin: Calibration, Validation and Uncertainty Analysis. Journal of Water Resource and Protection, 8, 397-410. https://doi.org/10.4236/jwarp.2016.83033

[20] Dai, J.-F., Chen, J.-Z., Lu, G.-A., Brown, L.C., Gan, L. and Xu, Q.-X. (2017) Application of SWAT992 to Sensitivity Analysis of Water Balance Components in Unique Plots in a Hilly Region. Water Science and Engineering, 10, 209-216. https://doi.org/10.1016/j.wse.2017.09.002

[21] Xue, L.J., Li, L.J. and Zhang, Q. (2008) Hydrological Behaviour and Water Balance Analysis for Xitiaoxi Catchment of Taihu Basin. Water Science and Engineering, 1, 44-53.

[22] Stehr, A., Debels, P., Romero, F. and Alcayaga, H. (2008) Hydrological Modelling with SWAT under Conditions of Limited Data Availability: Evaluation of Results from a Chilean Case Study. Hydrological Sciences Journal, 53, 588-601. https://doi.org/10.1623/hysj.53.3.588

[23] Tadesse, W., Whitaker, S., Crosson, W. and Wilson, C. (2015) Assessing the Impact of Land-Use Land-Cover Change on Stream Water and Sediment Yields at a Watershed Level Using SWAT. Open Journal of Modern Hydrology, 5, 68-85. https://doi.org/10.4236/ojmh.2015.53007

[24] Jothiprakash, V., Praveenkumar, C. and Manasa. M. (2017) Daily Runoff Estimation in Musi River Basin, India, from Gridded Rainfall Using SWAT Model. European Water, 57, 63-69.

[25] Bachmann, J. (2015) Analyse de la sensibilité du modèle SWAT à la précision des données pédologiques sur deux bassins de Bourgogne (France): Modélisation à partir de la base Données sol Université de Bourgogne UMR 5561 Bio géosciences Mémoire d'ingénieur agronome.

[26] Abbasa, N., Wasimia, S.A. and Al-Ansari, N. (2016) Assessment of Climate Change Impact on Water Resources of Lesser Zab, Kurdistan, Iraq Using SWAT Model. Engineering, 8, 697-715. https://doi.org/10.4236/eng.2016.810064

[27] Abbasa, N., Wasimia, S.A. and Al-Ansari, N. (2016) Assessment of Climate Change Impacts on Water Resources of Al-Adhaim, Iraq Using SWAT Model. Engineering, 8, 716-732. https://doi.org/10.4236/eng.2016.810065

[28] Mehan, S., Kannan, N., Neupane, R.P., Mcdaniel, R. and Kumar, S. (2016) Climate Change Impacts on the Hydrological Processes of a Small Agricultural Watershed. Climate, 4, 56. https://www.mdpi.com/journal/climate https://doi.org/10.3390/cli4040056

[29] Fontaine, T.A., Klassen, J.F., Cruickshank, T.S. and Hotchkiss, R.H. (2001) Hydrological Response to Climate Change in the Black Hills of South Dakota. Hydrologi- 
cal Sciences Journal, 46, 27-40. https://doi.org/10.1080/02626660109492798

[30] Bouslihim, Y., Kacimi, I., Brirhet, H., Khatati, M., Rochdi, A., Pazza, N.E.A., Miftah, A. and Yaslo, Z. (2016) Hydrologic Modeling Using SWAT and GIS, Application to Subwatershed Bab-Merzouka (Sebou, Morocco). Journal of Geographic Information System, 8, 20-27. https://doi.org/10.4236/jgis.2016.81002

[31] Anaba, L.A., Banadda, N., Kiggundu, N., Wanyama, J., Engel, B. and Moriasi, D. (2017) Application of SWAT to Assess the Effects of Land Use Change in the Murchison Bay Catchment in Uganda. Computational Water, Energy, and Environmental Engineering, 6, 24-40. https://doi.org/10.4236/cweee.2017.61003

[32] Badji, A.M. (2007) Modélisation de la relation pluie-débit et prévision des crues et des étiages sur l'exemple du bassin versant de la Falémé. Mémoire de DEA en vue d'obtenir le Diplôme d'Etude Approfondie en physique. Université Cheikh Anta DIOP de Dakar, Dakar.

[33] Cisse, S. (2009) Étude du fonctionnement hydrologique du bassin de la Falémé en amont de Kidira: Application du modèle hydrologique distribué SWAT. Mémoire de DEA en vue d'obtenir le Diplôme d'Etude Approfondie en physique. Université Cheikh Anta DIOP de Dakar, Dakar.

[34] Boye, M. (2009) Modélisation de la relation pluie-débit dans le bassin amont du fleuve Sénégal. Mémoire de DEA en vue d'obtenir le Diplôme d'Etude Approfondie en physique. Université Cheikh Anta DIOP de Dakar, Dakar.

[35] OMVS (2013) Actualisation de la monographie hydrologique du fleuve Sénégal. Rapport final février 2013.

[36] Sane, M.L., Sambou, S., Ndione, D.M., Leye, I., Kane, S. and Badji, M.L. (2017) Analyse et traitement des séries de débits annuels et mensuels sur le Fleuve Sénégal en amont du barrage de Manantali: cas des stations de Bafing Makana et Dakka Saidou. Revue Ivoirienne des Sciences et Technologie, 30, 102-120. https://revist.net/REVIST 30/REVIST 30 7.pdf

[37] https://fr.climate-data.org/afrique/senegal-187/

[38] Arnold, J.G. and Fohrer, N. (2005) Current Capabilities and Research Opportunities in Applied Watershed Modeling. Hydrological Processes, 19, 563-572. https://doi.org/10.1002/hyp.5611

[39] Mamo, K.H.M. and Jain, M.K. (2013) Runoff and Sediment Modeling Using SWAT in Gumera Catchment, Ethiopia. Open Journal of Modern Hydrology, 3, 196-205. http://www.scirp.org/journal/ojmh https://doi.org/10.4236/ojmh.2013.34024

[40] Faiza, H., Mohamed, M., Gil, M. and Alaheddine, S. (2015) Modélisation de la qualité des eaux naturelles cas du barrage de Sidi M’Hamed Ben Aouda dans le bassin de l'oued Mina (Nord-Ouest d'Algérie) Article.

[41] Da Silva, M.G., De Aguiar Netto, A.D.O., De Jesus Neves, R.J., Do Vasco, A.N., Almeida, C. and Faccioli, G.G. (2015) Sensitivity Analysis and Calibration of Hydrological Modeling of the Watershed Northeast Brazil. Journal of Environmental Protection, 6, 837-850. http://www.scirp.org/journal/jep https://doi.org/10.4236/jep.2015.68076

[42] Zang, X.S., Srinivasan, R. and Van Liew, M. (2009) On the Use of Multi-Algorithm, Genetically Adaptive Multi-Objective Method for Multi-Site Calibration of the SWAT Model. Hydrological Processes, 24, 955-969. http://www.interscience.wiley.com

[43] Omer, A., Wang, W.G., Basheer, A.K. and Yong, B. (2017) Integrated Assessment of the Impacts of Climate Variability and Anthropogenic Activities on River Runoff: A 
Case Study in the Hutuo River Basin, China. Hydrology Research, 482, 416-430. https://doi.org/10.2166/nh.2016.229

[44] Nolwenn, P. (2013) Ruissellement, érosion et inondation: Modélisation hydrologique du bassin versant de la Hyse et mise en place d'un partenariat. Rapport de stage 13 janvier 2003/13 juillet 2003 .

[45] Arias, R., Rodríguez-Blanco, M.L., Taboada-Castro, M.M., Nunes, J.P., Keizer, J.J. and Taboada-Castro, M.T. (2014) Water Resources Response to Changes in Temperature, Rainfall and $\mathrm{CO}_{2}$ Concentration: A First Approach in NW Spain. Water, 6, 3049-3067. https://doi.org/10.3390/w6103049

[46] Jin, H., Zhu, Q., Zhao, X.H. and Zhang, Y.B. (2016) Simulation and Prediction of Climate Variability and Assessment of the Response of Water Resources in a Typical Watershed in China. Water, 8, 490. http://www.mdpi.com/journal/water https://doi.org/10.3390/w8110490

[47] Gassman, P.W., Reyes, M.R., Green, C.H. and Arnold, J.G. (2007) The Soil and Water Assessment Tool: Historical Development, Applications, and Future Research Directions. CARD Working Papers, 477.

http://lib.dr.iastate.edu/card workingpapers/477

[48] Ghoraba, S.M. (2015) Hydrological Modeling of the Simly Dam Watershed (Pakistan) Using GIS and SWAT Model 1110-0168 a 2015 Faculty of Engineering, Alexandria University. Production and Hosting by Elsevier B.V. This Is an Open Access Article under the CC BY-NC-ND License. http://dx.doi.org/10.1016/j.aej.2015.05.018

[49] Guo, S.S., Zhu, Z. and Lyu, L. (2018) Effects of Climate Change and Human Activities on Soil Erosion in the Xihe River Basin, China. Water, 10, 1085.

http://www.mdpi.com/journal/water https://doi.org/10.3390/w10081085

[50] Grusson, Y. (2016) Modélisation de l'évolution hydroclimatique des flux et stocks d'eau verte et d'eau bleue du bassin versant de la Garonne. Thèse en cotutelle Doctorat en génie des eaux, 70-90.

[51] Boithias, L., Sauvage, S., Lenica, A., Roux, H., Abbaspour, K.C., Larnier, K., Dartus, D. and Sánchez-Pérez, J.M. (2017) Simulating Flash Floods at Hourly Time-Step Using the SWAT Model. Water, 9, 929. http://www.mdpi.com/journal/water https://doi.org/10.3390/w9120929

[52] Jha, M. (2009) Hydrologic Simulations of the Maquoketa River Watershed Using SWAT Working Paper 09-WP 492 June 2009. Center for Agricultural and Rural Development, Iowa State University, Ames, IA.

https://www.card.iastate.edu/products/publications/pdf/09wp492.pdf

[53] Jain, S.K., Tyagi, J. and Singh, V. (2010) Simulation of Runoff and Sediment Yield for a Himalayan Watershed Using SWAT Model. Journal of Water Resource and Protection, 2, 267-281. http://www.scirp.org/journal/jwarp https://doi.org/10.4236/jwarp.2010.23031

[54] Mathevet, T., Michel, C., Andréassian, V. and Perrin, C. (2006) A Bounded Version of the Nash-Sutcliffe Criterion for Better Model Assessment on Large Sets of Basins. In: Large Sample Basin Experiments for Hydrological Model Parameterization: Results of the Model Parameter Experiment-MOPEX, IAHS Publication 307, AISH, 211-219.

[55] Sood, A., Muthuwatta, L. and McCartney, M. (2013). A SWAT Evaluation of the Effect of Climate Change on the Hydrology of the Volta River Basin. Water International, 38, 297-311. https://doi.org/10.1080/02508060.2013.792404

[56] Mishra, A., Singh, R. and Singh, V.P. (2010) Evaluation of Non-Point Source N and 
P Loads in a Small Mixed Land Use Land Cover Watershed. Journal of Water Resource and Protection, 2, 362-372. https://doi.org/10.4236/jwarp.2010.24042 http://www.SciRP.org/journal/jwarp

[57] Leye, I., Sambou, S., Sane, M.L., Ndiaye, I., Ndione, D.M., Kane, S., Diatta, S., et al. (2020) Hydrological Modeling of an Ungauged River Basin Using SWAT Model for Water Resource Management Case of Kayanga River Upstream Niandouba Dam. Journal of Water Resources and Ocean Science, 9, 29-41.

https://doi.org/10.11648/j.wros.20200901.14 